\title{
USERS' PERCEPTIONS AND ATTITUDES TOWARDS EDIBLE CAMPUS
}

\author{
T.-I. LEE, Y.-H. CHOU \& T.-N. HUANG \\ Department of Horticultural Science, National Chiayi University, Taiwan.
}

\begin{abstract}
Urban agriculture has been regarded as a strategy towards sustainable urban development. It can transform abandoned or underutilized public or semi-public lands into productive space with landscape plants as well as edible crops. Similar to other green space, the edible landscape can provide a range of ecosystem services. However, it could also encounter vandalism and require more inputs into the maintenance, such as irrigation, fertilizing, weeding, pest control, pruning, and harvesting. Thus, the way in which how users perceive edible landscape can affect the delivery of the concept. Among the edible landscape, edible campus is one of the most popular types. They are semi-public space, which surrounds public institutions and is open to the public while imposes a set of stricter rules on users' behaviours than outside. Given the qualities, edible landscape may be more likely to be delivered and maintained in such a semi-public space than in a public space. In Taiwan, edible campuses are often at an elementary school level. Colleges and universities, on the other hand, have their own farms to support agriculture-related practicums and thus pay less attention to the creation of edible campus. However, campuses at a college or university level tend to be more open to the public than at other educational level. Given its semi-public quality, they serve as a pertinent case to explore how users view edible landscape. Through survey, this study collects 406 data from onsite distribution between March and April in 2017 in National Chiayi University, Taiwan. The results reveal that although the concept is unfamiliar to most of the users, they are willing to support the idea of edible campus. In addition, the findings show that users' positive knowledge of edible landscape has association with their support for edible landscape. However, the users' knowledge perception does not have association with their support.
\end{abstract}

Keywords: edible landscape, edible school, maintenance, productive space

\section{INTRODUCTION}

Edible landscapes are defined as spaces greened and beautified by using edible crops and/or traditional landscape plants. As a type of green infrastructure components, edible landscapes are increasingly perceived as, not only productive spaces contributing to food security and social well-being [1], but also recreational spaces having potential to beautify underutilized sites, foster social cohesion and community development [2], and increase biodiversity and provide ecosystem services [3].

Given the multiple functions and values, edible landscapes are addressed in an urban or peri-urban more often, than in a rural context, as an approach to sustainable urban development or regeneration. In comparison with farmlands or other urban green spaces, the term suggests it pays more attention to both productive and aesthetic quality. Sometimes, urban agriculture is a synonym for edible landscape as being referred to a range of edible spaces, including green walls, rooftop gardens, back yards, roadside greens, community gardens, allotments, urban parks, farmlands, nursery, and greenhouses [4]. However, urban agriculture can be defined as a term with a wider range of urban production activities, including crops, animals, and even non-food products, such as aromatic and medicinal herbs, ornamental plants, and tree products [5].

The edible landscape in urban public lands may concern visual aesthetics, crop harvest, as well as the needs and limitations of an urban environment. The feature concerning multiple 
facets can complicate the establishment and management of edible landscapes in urban public lands. For example, vandalism is a challenge concerned when the Edible Campus project was developed at the McGill University in downtown Montreal [6]. In addition, Seattle's urban forest management plan excludes gathering as a legitimate activity; thus, the management encounters conflicts when fruit harvesting groups regard the forest as a source of food with their roots in the food security movement [7].

Through developing design techniques, neighbourhoods can create edible landscape with decorative, productive, and other functions in a densely built urban environment. Among these edible landscapes, edible campuses are a common type which helps to demonstrate how edible landscape can be woven into urban spaces [6] and connected to the sustainability of urban development [8]. For instance, Bhatt et al. [6] reported the Edible Campus project turning underutilized urban spaces into productive places by incorporating ecological containers to grow crops on paved areas on the downtown campus of McGill University (Fig. 1). However, previous studies focusing on edible campus are at elementary or middle school level and thus pay attention to the educational effects of these garden programs on, for example, students' constructs of life skills [9], or their knowledge, attitudes, and behaviours associated with vegetable consumption [10].

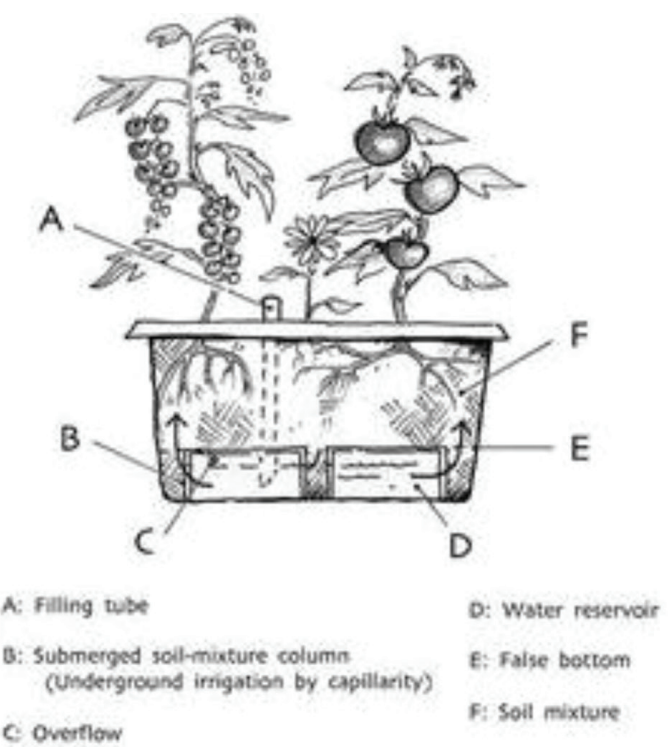

(a)

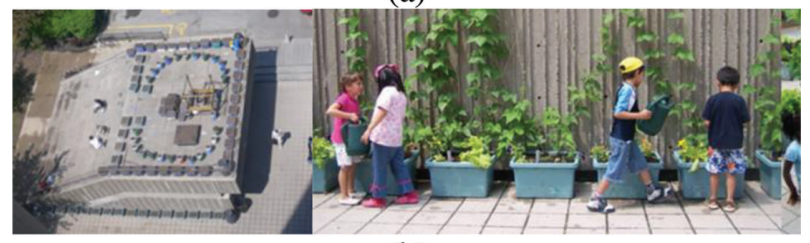

(b)

Figure 1: Edible Campus projects on McGill University's downtown campus. (a) The ecological containers; (b) photos of the edible campus.

Source: [6]. 
Although there are cases found worldwide transforming public open spaces in downtown areas, such as Lafayette Greens, Detroit, into edible ones [11], edible plazas as an alternative to traditional greening of public open spaces are still rare. Some studies have focused on how the existing or potential users perceive edible landscape in Western culture. For instance, Sany-Mengual et al. uses semi-structured interviews with stakeholders in Barcelona, Spain and discovered that urban agriculture is largely perceived as a social activity rather than a food production initiative [12]. However, little research has been conducted to analyse the attitudes of potential users of edible plazas in the Eastern Countries. To address these knowledge gaps, this paper examines the main research question: What are the potential users' attitudes towards the hypothetical establishment and management of edible landscaping in underutilized campus plazas as an alternative to the existing greening? In addition, it analyses whether users' supports to the concept of the edible plazas show differences among indexes of their backgrounds, perceptions of edible landscape, and attitudes towards urban agriculture.

\section{RESEARCH DESIGN}

\subsection{Study area}

The National Chiayi University in Chiayi, Taiwan $\left(120.27^{\circ} \mathrm{E}, 23.29^{\circ} \mathrm{N}\right)$ is selected as the study area. The National Chiayi University has a population over 13,903 people, including visitors, 12,545 students, 497 faculties, and 861 staffs based on the statistics of the university [13]. It has four campuses scattered at different locations in and around the city. They are Lantan Campus, Minsyong Campus, Linsen Campus, and Sinmin Campus (Fig. 2) and each has its own central libraries. In front of the four libraries, there are plazas with traditional greening rather than edible landscaping. The four plazas in front of the central libraries of each campus (Fig. 2) are selected because they tend to be paved open spaces, where movable crop planters can be easily placed. They are underutilized and, thus, subject to revitalization. In addition, they are highly visible and recognizable to the campus users, so the respondents can easily recall how the places look like.

\subsection{Questionnaires}

A questionnaire is designed to investigate what campus users including staff, faculties, undergraduates, graduates, and visitors perceive the establishment and management of edible plazas on a hypothetical situation, in which edible landscape replaces the existing landscape of the underutilized plaza in the National Chiayi University, Taiwan. The survey was conducted from March 2017 to April 2017. The questionnaires were distributed to users of those busy places on campus during noontime, such as school restaurants, sport fields, and libraries. Questionnaires are disseminated on both working days or non-working days in order to collect data from a wide range of campus users with different purposes, i.e. study, work, or recreation.

We divided the questionnaire into three sections: first, the demographic characteristics backgrounds of the respondents, their planting experience, and their place of residence; second, attitudes towards edible campus (Fig. 1) using ecological containers [6] in replace with the existing landscape of the paved plaza (Fig. 2); finally, opinions on the establishment and management of the edible plaza. 


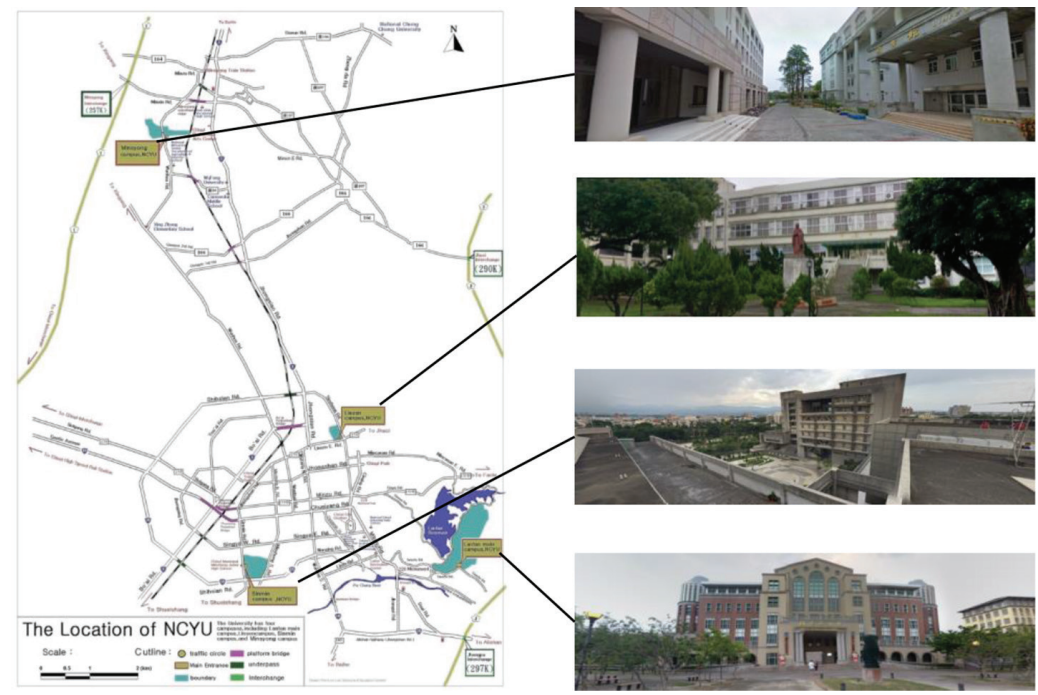

(a)

(b)

(c)

Figure 2: Location map of the four plazas in front of the central libraries in National Chiayi University campuses. (a) Campus Lantan; (b) Campus Minsyong; (c) Campus Linsen; (d) Campus Sinmin.

Source: $[13,14]$.

\section{RESULTS}

\subsection{Basic information of respondents}

A total of 406 campus users were surveyed face-to-face on the four campus users randomly with the questionnaire, accounting for about $29.2 \%$ of the overall population of the study. The basic information for all respondents is presented (Table 1). This sample consists of 234 women (57.6\%) and 172 men (42.4\%), roughly indicating the area's gender balance. The age groups 2630 and 3140 were represented in same proportions: $4.4 \%$ respectively, which was slightly higher than the proportion $(1.2 \%)$ of respondents over 41 years old. No respondents indicated that they were less than 18 years of age.

Respondents indicated their locations on the Campus Lantan accounting for 52.7\%, Minsyong accounting for $22.7 \%$, Linsen accounting for $3.2 \%$, and Sinmin accounting for $21.4 \%$. On education background, the survey participants were mainly $(89.4 \%)$ undergraduates, while people who had other level of educational backgrounds were much lower: junior high school education $(0.2 \%)$, senior high school education (3.4\%), and graduate education (7.1\%). Regarding the position, $89.4 \%$ of the respondents were students, $3.9 \%$ were faculties and staff, and $6.7 \%$ were visitors. Regarding the age of respondents, the majority was between 18 and 25 years old $(89.9 \%)$.

Regarding the residence, most respondents lived in urban areas $(55.7 \%)$, while respondents lived in rural and suburban areas represented in roughly same proportions: 20.2 and $24.1 \%$, respectively. In addition, although the majority of respondents $(72.9 \%)$ did not have farming training, the majority of respondents $(63.1 \%)$ had farming experience.

Table 1 also shows the campus users' familiarity and recognition of edible landscaping. Although most people (72\%) indicated their unfamiliarity with edible landscaping, a higher proportion $(96 \%)$ of the respondents agreed with the presence of agricultural activities in urban areas. 
Table 1: Basic information of respondents $(N=406)$.

\begin{tabular}{|c|c|c|c|}
\hline Item & Group & Number & Proportion (\%) \\
\hline \multirow[t]{2}{*}{ Gender } & Male & 172 & 42.4 \\
\hline & Female & 234 & 57.6 \\
\hline \multirow[t]{6}{*}{ Age } & $<18$ & 0 & 0 \\
\hline & $18-25$ & 365 & 89.9 \\
\hline & $26-30$ & 18 & 4.4 \\
\hline & $31-40$ & 18 & 4.4 \\
\hline & $41-65$ & 4 & 1.0 \\
\hline & $>66$ & 1 & 0.2 \\
\hline \multirow[t]{4}{*}{ Campus } & Lantan & 214 & 52.7 \\
\hline & Minsyong & 92 & 22.7 \\
\hline & Linsen & 13 & 3.2 \\
\hline & Sinmin & 87 & 21.4 \\
\hline \multirow[t]{4}{*}{ Education } & Junior high & 1 & 0.2 \\
\hline & Senior high & 14 & 3.4 \\
\hline & Undergraduate & 362 & 89.2 \\
\hline & Graduate & 29 & 7.1 \\
\hline \multirow[t]{4}{*}{ Position } & Student & 363 & 89.4 \\
\hline & Faculty & 5 & 1.2 \\
\hline & Staff & 11 & 2.7 \\
\hline & Visitor & 27 & 6.7 \\
\hline \multirow[t]{3}{*}{ Residence } & Rural & 82 & 20.2 \\
\hline & Suburban & 98 & 24.1 \\
\hline & Urban & 226 & 55.7 \\
\hline \multirow[t]{2}{*}{ Agricultural training } & Yes & 110 & 27.1 \\
\hline & No & 296 & 72.9 \\
\hline \multirow[t]{2}{*}{ Farming experience } & Yes & 256 & 63.1 \\
\hline & No & 150 & 36.9 \\
\hline \multirow[t]{2}{*}{ Familiarity with the term } & Yes & 113 & 28 \\
\hline & No & 293 & 72 \\
\hline \multirow[t]{2}{*}{ Urban agriculture } & Agree & 391 & 96 \\
\hline & Not agree & 15 & 4 \\
\hline
\end{tabular}

3.2 Subjective knowledge towards edible plazas

In comparison with traditional landscaping and greening, we investigate the campus users' subjective knowledge towards edible plazas. Each item was evaluated individually on a fivepoint Likert-scale. Table 2 displays the mean and standard deviation. Results show that campus users feel edible plazas need more maintenance than the traditional landscape. In addition, they think edible plazas are more educative, attractive, sustainable, beautiful, and providing more functions than the traditional ones. However, edible plazas are also regarded as being more subject to vandalism. In addition, the mean of the statements that edible plazas 
Table 2: Subjective knowledge towards edible plazas $(N=406)$.

\begin{tabular}{llll}
\hline Item & Mean & Median & SD \\
\hline Need more maintenance & 4.14 & 4 & 0.850 \\
More educative & 4.10 & 4 & 0.852 \\
Provide more functions & 3.86 & 4 & 0.852 \\
More attractive & 3.83 & 4 & 0.944 \\
More subject to vandalism & 3.81 & 4 & 0.971 \\
More sustainable & 3.69 & 4 & 1.003 \\
More beautiful & 3.40 & 3 & 0.973 \\
Consume more energy & 2.97 & 3 & 1.068 \\
Smellier & 2.95 & 3 & 1.022 \\
\hline
\end{tabular}

Note: $\mathrm{SD}=$ standard deviation.

consume more energy and are smellier than traditional landscaping are below the midpoint three indicating general disagreement.

\subsection{Attitudes towards the management of edible plazas}

We then investigated attitudes towards the maintenance of edible plazas. Each item was evaluated individually on a five-point Likert-scale. Results in Table 3 show that regarding maintenance, chemical compounds prohibited, social activities held on a regular basis, and selling the harvests are most valued management by the campus users. However, the mean of the statement harvesting activities open to the public is below the midpoint three indicating general disagreement.

\subsection{General attitudes towards of edible plazas}

Afterwards, we investigated campus users' attitudes towards edible plazas (Table 4). Each item was evaluated individually on a five-point Likert-scale. Campus users agree the most with the ideas that edible plazas are a form of campus greening as well as a form of urban agriculture. In addition, they think edible plazas are appropriate and show willingness to support the concept of edible plazas. However, campus users show less agreement on the susceptibility to contamination and the nontoxicity of the edible plazas. Although they show

Table 3: Managerial attitudes towards edible plazas $(N=406)$.

\begin{tabular}{llll}
\hline Item & Mean & Median & SD \\
\hline Chemical compounds prohibited & 4.04 & 4 & 0.979 \\
Social activities held on a regular basis & 3.92 & 4 & 0.579 \\
Selling the harvests & 3.92 & 4 & 0.859 \\
Managing the harvests & 3.83 & 4 & 0.936 \\
Harvesting open to the public & 2.88 & 3 & 1.099 \\
\hline
\end{tabular}

Note: $\mathrm{SD}=$ standard deviation. 
Table 4: General attitudes towards edible plazas $(N=406)$.

\begin{tabular}{llll}
\hline Item & Mean & Median & SD \\
\hline It is a form of campus greening & 4.06 & 4 & 0.775 \\
I am willing to support it & 3.99 & 4 & 0.815 \\
It is a form of urban agriculture & 3.96 & 4 & 0.782 \\
It is appropriate & 3.86 & 4 & 0.797 \\
I will eat the harvests & 3.80 & 4 & 0.896 \\
It is subject to contamination & 3.67 & 3 & 1.047 \\
It is nontoxic & 3.57 & 4 & 0.883 \\
I will pick up the harvests & 3.46 & 4 & 1.057 \\
\hline
\end{tabular}

Note: $\mathrm{SD}=$ standard deviation.

more willingness to eat the harvest, they show less willingness to pick up the harvests. Overall, the mean of the statements are above the midpoint three indicating general agreement.

The data were analysed using exploratory factor analysis. Table 5 shows the rotated component matrix. Through the analyses, seven were deleted from the 22 questions due to a loading value below 0.5 or a cross-loading issue. The KaiserMeyerOlkin (KMO) criterion is 0.821, which is considered to be meritorious. Through the factor analysis, the following five factors were found to indicate campus users' attitudes:

Factor 1 (F1): Merits of edible plazas

Contains positive items which express that edible plazas would be more sustainable, attractive, educative, and beautiful and they would provide more functions than the existing plazas. The Cronbach's alpha measures 0.802 , which is considered to be good.

Factor 2 (F2): Food safety issues of edible plazas

Sums up items in relation to food safety which express that the campus users would pick up, eat the harvests from crops grown on the edible plazas, and the harvests would be nontoxic. The Cronbach's alpha measures 0.734 , which is considered to be acceptable.

Factor 3 (F3): Demerits of edible plazas

Contains negative items which express that edible plazas would be smellier, subject to contamination, and they would consume more energy. The Cronbach's alpha measures 0.705, which is considered to be acceptable.

Factor 4 (F4): Support for edible plazas

Sums up statements concerning support for the edible plazas, such as the recognition of the edible plazas as a form of urban agriculture and campus greening and the willingness to support the edible plazas. The Cronbach's alpha measures 0.738 , which is considered to be acceptable.

Factor 5 (F5): Management of edible plazas

Contains merely a managerial item expressing that harvesting the edible parts of the crops grown on the edible plazas should be open to the public.

\subsection{Perception and attitude determinants of support for edible plazas}

The analysis tests how factors and indexes of perceptions and attitudes affect campus users' intentions towards for edible plazas. Table 6 presents results from Spearman's correlation coefficient Rho measures, investigating the influence of merits, demerits, food safety, 
Table 5: Attitudes rotated factor loading matrix $(N=406)$.

Com-

Factor 1 Factor 2 Factor 3 Factor 4 Factor 5 munality

\begin{tabular}{|c|c|c|c|c|c|c|}
\hline KMO: 0.821 & Merit & Safety & Demerit & Support & Manage & \\
\hline Sum of squared loading & 4.488 & 1.964 & 1.349 & 1.057 & 1.012 & \\
\hline $\begin{array}{l}\text { Percentage of variance ex- } \\
\text { plained }(\%)\end{array}$ & 29.920 & 13.095 & 8.991 & 7.056 & 6.747 & \\
\hline $\begin{array}{l}\text { Cumulative percentage of vari- } \\
\text { ance }\end{array}$ & 29.920 & 43.016 & 52.006 & 59.062 & 65.809 & \\
\hline Cronbach's alpha & 0.802 & 0.734 & 0.705 & 0.738 & - & \\
\hline $\begin{array}{l}\text { The edible plaza would be more } \\
\text { sustainable }\end{array}$ & 0.763 & 0.232 & -0.098 & 0.077 & 0.005 & 0.651 \\
\hline $\begin{array}{l}\text { The edible plaza would be more } \\
\text { attractive }\end{array}$ & 0.735 & 0.130 & 0.109 & 0.198 & 0.120 & 0.623 \\
\hline $\begin{array}{l}\text { The edible plaza would be more } \\
\text { educative }\end{array}$ & 0.702 & 0.119 & -0.013 & 0.067 & -0.032 & 0.512 \\
\hline $\begin{array}{l}\text { The edible plaza would be more } \\
\text { beautiful }\end{array}$ & 0.701 & 0.051 & 0.053 & 0.175 & 0.028 & 0.529 \\
\hline $\begin{array}{l}\text { The edible plaza would provide } \\
\text { more functions }\end{array}$ & 0.682 & 0.136 & 0.120 & 0.216 & -0.043 & 0.546 \\
\hline I would pick up the harvests & 0.216 & 0.822 & -0.065 & 0.123 & -0.048 & 0.749 \\
\hline I would eat the harvests & 0.200 & 0.817 & 0.070 & 0.063 & 0.178 & 0.744 \\
\hline The harvests would be nontoxic & 0.115 & 0.681 & 0.049 & 0.190 & -0.131 & 0.532 \\
\hline $\begin{array}{l}\text { The edible plaza would be } \\
\text { smellier }\end{array}$ & -0.008 & 0.079 & 0.809 & -0.045 & -0.118 & 0.676 \\
\hline $\begin{array}{l}\text { The edible plaza would consume } \\
\text { more energy }\end{array}$ & 0.016 & 0.026 & 0.807 & 0.167 & 0.029 & 0.681 \\
\hline $\begin{array}{l}\text { The harvest would be subject to } \\
\text { contamination }\end{array}$ & 0.087 & -0.062 & 0.744 & -0.093 & 0.097 & 0.584 \\
\hline $\begin{array}{l}\text { The edible plaza would be a form } \\
\text { of campus greening }\end{array}$ & 0.176 & 0.198 & -0.094 & 0.817 & 0.049 & 0.749 \\
\hline $\begin{array}{l}\text { The edible plaza would be a form } \\
\text { of urban agriculture }\end{array}$ & 0.265 & 0.069 & 0.173 & 0.762 & -0.016 & 0.686 \\
\hline $\begin{array}{l}\text { I am willing to support the edible } \\
\text { plaza }\end{array}$ & 0.463 & 0.318 & -0.142 & 0.566 & 0.048 & 0.658 \\
\hline $\begin{array}{l}\text { Harvesting of the edible plaza } \\
\text { should be open to the public }\end{array}$ & 0.033 & -0.016 & 0.011 & 0.041 & 0.974 & 0.952 \\
\hline
\end{tabular}

Note: $\mathrm{KMO}=$ KaiserMeyerOlkin criterion.

management, subjective knowledge, managerial attitude, and general attitude on the support for edible plazas.

Looking at the merit factors (F1), the results show that a general recognition of the merits of edible landscapes increases support for the edible campus. However, the demerit factors (F3) have no significant impact on the support of edible campus. Furthermore, the food safety factors (F2) have a significant and positive effect on campus users' support for the 
Table 6: Perception and attitude determinants of support for edible campus ( $N=406)$.

\begin{tabular}{|c|c|c|}
\hline & F4 & $\begin{array}{l}\text { I am willing to support the } \\
\text { edible plaza }\end{array}$ \\
\hline Items & rs & rs \\
\hline F1: Merits & $0.529 *$ & $0.510 *$ \\
\hline F2: Food safety & $0.422 *$ & $0.437 *$ \\
\hline F3: Demerits & -0.28 & -0.084 \\
\hline F5: Management & 0.69 & 0.44 \\
\hline Subjective knowledge index & $0.425^{*}$ & $0.369 *$ \\
\hline Managerial attitude index & $0.374 *$ & $0.270 *$ \\
\hline General attitude index & $0.773 *$ & $0.710 *$ \\
\hline
\end{tabular}

edible plaza. In addition, the indexes of subjective knowledge, managerial attitude, and general attitude have a significant and positive influence on campus users' support for the edible plazas.

\subsection{Background determinants of support for edible campus}

The analysis is completed by examining how indexes of background affect campus users' intentions towards for edible plazas. Table 7 presents results from $t$-test and one-way ANOVA (analysis of variance) measures, investigating the influence of gender, age, campus, education, position, residence, agricultural training, farming experience, familiarity with edible campus, and recognition to urban agriculture on the support for edible plazas.

For the indexes of gender, agricultural training, farming experience, familiarity with edible campus, and urban agriculture, the results of $t$-test present that these indexes do not have significant effect on campus users' support for the edible plaza or F4.

Table 7: Background determinants of support for edible campus ( $\mathrm{N}=406)$.

\begin{tabular}{lllll}
\hline Item & \multicolumn{3}{l}{ Support } & $\mathrm{F} 4$ \\
\cline { 2 - 5 } & $\mathrm{F}$ & $\mathrm{P}$ & $\mathrm{F}$ & $\mathrm{P}$ \\
\hline Gender & 0.413 & 0.521 & 2.026 & 0.155 \\
Agricultural training & 3.861 & 0.050 & 5.044 & 0.025 \\
Farming experience & 0.402 & 0.526 & 0.006 & 0.937 \\
Familiarity with edible & 0.109 & 0.742 & 0.652 & 0.420 \\
campus & & & & \\
Urban agriculture & 0.244 & 0.621 & 0.176 & 0.675 \\
Age & 3.929 & $0.004 *$ & 2.728 & 0.029 \\
Campus & 0.188 & 0.904 & 0.620 & 0.602 \\
Education & 5.104 & $0.002 *$ & 2.405 & 0.067 \\
Position & 0.936 & 0.423 & 1.457 & 0.226 \\
Residence & 0.661 & 0.517 & 1.256 & 0.286 \\
\hline
\end{tabular}


Regarding the effect of the indexes of age, campus, education, position, and residence on campus users' support for the edible plaza, the $p$-values of all the indexes for the Levene statistic $(0.756 / p=0.519,1.823 / p=0.142,1.059 / p=0.348,0.411 / p=0.745$, and $3.526 / p=0.30$, respectively) are not significant ( $p>0.05$ ). Thus, the assumption of homogeneity of variances is tenable. The results of the ANOVA $F$-test present that only the indexes of Age and Education have significant effect on campus users' support for the edible plaza $(p<0.01)$.

Regarding the effect of the indexes of age, campus, education, position, and residence on $\mathrm{F} 4$, the $p$-values of all the indexes for the Levene statistic $(2.199 / p=0.088,1.127 / p=0.338$, $2.145 / p=0.118,2.644 / p=0.049^{*}$, and $0.792 / p=0.453$, respectively) are not significant $(p>0.05)$. Thus, the assumption of homogeneity of variances is tenable. The results of the ANOVA $F$-test present that no indexes have significant effect on F4 $(p<0.01)$.

\section{DISCUSSION AND CONCLUSION}

Edible landscape has gradually been recognized as providing a wide range of advantages and contributing to sustainability. However, it may also encounter vandalism, disadvantages, and other maintenance issue. Interestingly, although the campus users agree with advantages of edible plazas, they do not think edible plazas have disadvantages, such as consuming more energy or being smellier than the traditional ones. Given these advantages and disadvantages of edible landscape, this study examines whether users' subjective knowledge affects their supports for the hypothetical transformation of existing campus plazas into edible plazas. The findings show that users' positive knowledge of edible landscape has association with their support for edible landscape. However, the users' knowledge perception does not have association with their support. Similarly, Grebitus et al.'s study reveals that the index which encourage urban farm purchase has significant association with purchase likelihood, but the index prevent urban farm purchase does not have significant association with purchase likelihood [15].

Looking at the background characteristics of users, the users' agricultural experiences or training do not affect their support for edible plaza, whereas age and education affect their support for edible plaza. However, the results may be biased by the data concentration to a certain age and education range as almost $90 \%$ of respondents are undergraduate students within the age range between 18 and 25 years old. This forms the limitation of this research. Therefore, future studies can examine users' perception and attitude with a wider range of age, education, or other background characteristics. The hypothetical nature of this study is highlighted. The survey tests campus user's perceptions and attitudes on a hypothetical situation rather than an actual situation of edible plazas. Therefore, future research might include a real, non-hypothetical transformation of public urban places into other types of edible landscape, such as edible playgrounds, edible parks, edible avenues, or edible alleys. Finally, future surveys on willingness to pay for the transformation or the maintenance of the edible places would be beneficial. Overall, this study provides an outlook on the acceptance of edible landscape. It also shows which perception or attitudinal index affects the support for the hypothetical transformation of the existing plazas into edible one on campus.

\section{REFERENCES}

[1] Mok, H.F., Williamson, V.G., Grove, J.R., Burry, K., Barker, S.F. \& Hamilton, A.J., Strawberry fields forever? Urban agriculture in developed countries: a review. Agronomy for Sustainable Development, 34(1), 21-43, 2014. https://doi.org/10.1007/s13593-013-0156-7 
[2] Contesse, M., van Vliet, B.J.M. \& Lenhart, J., Is urban agriculture urban green space? A comparison of policy arrangements for urban green space and urban agriculture in Santiago de Chile. Land Use Policy, 71, 566-77, 2018. https://doi.org/10.1016/j.landusepol.2017.11.006

[3] Lin, B.B., Philpott, S.M. \& Jha, S., The future of urban agriculture and biodiversity-ecosystem services: challenges and next steps. Basic and Applied Ecology, 16(3), 189-201, 2015. https://doi.org/10.1016/j.baae.2015.01.005

[4] Cretella, A. \& Buenger, M.S., Food as creative city politics in the city of Rotterdam. Cities, 51, 1-10, 2016. https://doi.org/10.1016/j.cities.2015.12.001

[5] Urban agriculture; Food and Agriculture Organization of the United Nations (FAO), http://fao.org/urban-agriculture/en/ (accessed 26 August 2018).

[6] Bhatt, V., Farah, L.M., Luka, N. \& Wolfe, J.M., Making the edible campus: a model for food-secure urban revitalisation. Open House International, 34(2), 81-90, 2009.

[7] McLain, R., Poe, M. \& Hurley, P., Lecompte-Mastenbrook, J., Emery, M.R., Producing edible landscapes in Seattle's urban forest. Urban Forestry \& Urban Greening, 11(2), 187-94, 2012.

https://doi.org/10.1016/j.ufug.2011.12.002

[8] Fischer, D.B., Karle, S.J., Cremer, K., Huttner, E., Seebauer, M., Nowikow, U., Schütze, B., Voigt, P., Völker, S. \& Kowarik, I., Biodiverse edible schools: linking healthy food, school gardens and local urban biodiversity. Urban Forestry \& Urban Greening, in press.

[9] Robinson, C.W. \& Zajicek, J.M., Growing minds: the effects of a one-year school garden program on six constructs of life skills of elementary school children. HortTechnology, 15(3), 453-57, 2005.

[10] Ratcliffe, M.M., Merrigan, K.A., Rogers, B.L. \& Goldberg, J.P., The effects of school garden experiences on middle school-aged students' knowledge, attitudes, and behaviors associated with vegetable consumption. Health Promotion Practice, 12(1), 36-43, 2011. https://doi.org/10.1177/1524839909349182

[11] Philips, A., Designing Urban Agriculture: A Complete Guide to the Planning, Design, Construction, Maintenance and Management of Edible Landscapes, Wiley: Hoboken, 2013.

[12] Sanyé-Mengual, E., Orsini, F., Oliver-Solà, J., Rieradevall, J., Montero, J.I. \& Gianquinto, G., Techniques and crops for efficient rooftop gardens in Bologna, Italy. Agronomy for Sustainable Development, 35(4), 1477-88, 2015. https://doi.org/10.1007/s13593-015-0331-0

[13] Map of School Campus. National Chiayi University, http://ncyu.edu.tw/eng/content. aspx?site_content_sn=36655 (accessed 26th August 2018).

[14] Google Street View, https://google.com.tw/maps/ (accessed 26 August 2018).

[15] Grebitus, C., Printezis, I. \& Printezis, A., Relationship between consumer behavior and success of urban agriculture. Ecological Economics, 136, pp. 189-200, 2017. https://doi.org/10.1016/j.ecolecon.2017.02.010 